\title{
ADGRB3 wt Allele
}

National Cancer Institute

\section{Source}

National Cancer Institute. ADGRB3 wt Allele. NCI Thesaurus. Code C52059.

Human ADGRB3 wild-type allele is located within 6q12-q13 and is approximately 754 kb in length. This allele, which encodes adhesion $\mathrm{G}$ protein-coupled receptor B3 protein, plays a role in receptor signaling. 